Article

\title{
In Vitro Antileishmanial and Antischistosomal Activities of Anemonin Isolated from the Fresh Leaves of Ranunculus multifidus Forsk
}

\author{
Betelhem Sirak ${ }^{1,2} \mathbb{D}^{\circ}$, Kaleab Asres ${ }^{1, *}$, Asrat Hailu ${ }^{3}$, Mthandazo Dube ${ }^{4}{ }^{\oplus}$, Norbert Arnold ${ }^{4}$, Cecile Häberli ${ }^{5,6}$, \\ Jennifer Keiser ${ }^{5,6}\left(\mathbb{D}\right.$ and Peter Imming ${ }^{7, *}$
}

1 Department of Pharmaceutical Chemistry and Pharmacognosy, School of Pharmacy, College of Health Sciences, Addis Ababa University, Addis Ababa P.O. Box 1176, Ethiopia; betelhem.sirak@amu.edu.et

2 Department of Pharmacy, College of Medicine and Health Sciences, Arba Minch University, Arba Minch P.O. Box 21, Ethiopia

3 Department of Microbiology, Immunology and Parasitology, Faculty of Medicine, College of Health Sciences, Addis Ababa University, Addis Ababa P.O. Box 1176, Ethiopia; asrat.hailu@aau.edu.et

4 Department of Bioorganic Chemistry, Leibniz Institute of Plant Biochemistry, Weinberg 3, D-06120 Halle (Saale), Germany; mdube@ipb-halle.de (M.D.); Norbert.Arnold@ipb-halle.de (N.A.)

5 Swiss Tropical and Public Health Institute, Socinstr. 57, CH-4051 Basel, Switzerland; cecile.haeberli@swisstph.ch (C.H.); jennifer.keiser@swisstph.ch (J.K.)

6 University of Basel, CH-4051 Basel, Switzerland

7 Institut fuer Pharmazie, Martin-Luther-Universitaet Halle-Wittenberg, Kurt-Mothes-Str. 3, 06120 Halle (Saale), Germany

check for updates

Citation: Sirak, B.; Asres, K.; Hailu, A.; Dube, M.; Arnold, N.; Häberli, C.; Keiser, J.; Imming, P. In Vitro Antileishmanial and Antischistosomal Activities of Anemonin Isolated from the Fresh Leaves of Ranunculus multifidus Forsk. Molecules 2021, 26, 7473. https:// doi.org/10.3390/molecules26247473

Academic Editor:

Francesca Mancianti

Received: 4 November 2021

Accepted: 7 December 2021

Published: 10 December 2021

Publisher's Note: MDPI stays neutral with regard to jurisdictional claims in published maps and institutional affiliations.

Copyright: (c) 2021 by the authors. Licensee MDPI, Basel, Switzerland. This article is an open access article distributed under the terms and conditions of the Creative Commons Attribution (CC BY) license (https:/ / creativecommons.org/licenses/by/ $4.0 /)$.
* Correspondence: kaleab.asres@aau.edu.et (K.A.); peter.imming@pharmazie.uni-halle.de (P.I.)
Abstract: Leishmaniasis and schistosomiasis are neglected tropical diseases (NTDs) infecting the world's poorest populations. Effectiveness of the current antileishmanial and antischistosomal therapies are significantly declining, which calls for an urgent need of new effective and safe drugs. In Ethiopia fresh leaves of Ranunculus multifidus Forsk. are traditionally used for the treatment of various ailments including leishmaniasis and eradication of intestinal worms. In the current study, anemonin isolated from the fresh leaves of $R$. multifidus was assessed for its in vitro antileishmanial and antischistosomal activities. Anemonin was isolated from the hydro-distilled extract of the leaves of R. multifidus. Antileishmanial activity was assessed on clinical isolates of the promastigote and amastigote forms of Leishmania aethiopica and L. donovani clinical isolates. Resazurin reduction assay was used to determine antipromastigote activity, while macrophages were employed for antiamastigote and cytotoxicity assays. Antischistosomal assays were performed against adult Schistosoma mansoni and newly transformed schistosomules (NTS). Anemonin displayed significant antileishmanial activity with $\mathrm{IC}_{50}$ values of $1.33 \mathrm{nM}$ and $1.58 \mathrm{nM}$ against promastigotes and $1.24 \mathrm{nM}$ and $1.91 \mathrm{nM}$ against amastigotes of L. aethiopica and L. donovani, respectively. It also showed moderate activity against adult S. mansoni and NTS (49\% activity against adult S. mansoni at $10 \mu \mathrm{M}$ and $41 \%$ activity against NTS at $1 \mu \mathrm{M}$ ). The results obtained in this investigation indicate that anemonin has the potential to be used as a template for designing novel antileishmanial and antischistosomal pharmacophores.

Keywords: Ranunculus multifidus; fresh leaves; antileishmanial activity; Leishmania aethiopica; Leishmania donovani; promastigotes; amastigotes; macrophage; selectivity index; anemonin

\section{Introduction}

Leishmaniasis is a neglected tropical disease (NTD) infecting the world's poorest populations. According to WHO [1], an estimated 700,000 to 1,000,000 new cases of leishmaniases occur annually. The disease is endemic and highly prevalent in Ethiopia where people in the highlands are at higher risk of contracting cutaneous leishmaniasis, while visceral leishmaniasis is prevalent mostly in lowland arid areas of the country [2-6]. Efficacy, 
toxicity, cost and availability of drug are among factors determining the choice of drug to treat leishmaniasis [7]. The effectiveness of currently available drugs is significantly declining due to increased drug resistance, emerging cross resistance, requirements for parenteral administration and/or length of treatment, lack of new drugs with novel mechanisms of action and unavailability of effective vaccine [8-12]. This has highlighted the urgent need to explore traditionally used medicinal plants as a source of new antileishmanial drugs in order to minimize the debilitating impact of the disease.

In Ethiopia, Ranunculus multifidus Forsk. (Ranunculaceae) is commonly known by its vernacular names such as 'Etse siol' (Geez), 'Gundi' (Amharic), 'Tuche or Aysmamata' (Gamo), 'Abba warqe' (Afaan Oromo) and 'Hogioo' (Kaffa) [13-15]. In traditional medicine, dried and crushed roots and leaves of R. multifidus are used to clear out intestinal worms [16]. The leaves are also applied topically to treat leishmaniasis in different parts of Ethiopia. In some parts of the country the dried leaves are pounded to powder and mixed with honey and applied on wounds caused by visceral leishmaniasis [17], while in other parts fresh leaves are crushed and rubbed on the affected part [18]. However, despite the popularity of the plant in traditional medicine for the control of leishmaniasis and eradication of intestinal worms, no phytochemical or biological studies concerning the activity of the plants against leishmaniasis could be found in the literature. The genus Ranunculus has however been established as an anti-inflammatory, analgesic, antiviral, antibacterial, antiparasitic and antifungal agent due to the presence of anemonin [19].

Schistosomiasis is the most widely distributed chronic NTD affecting people living in communities where poor environmental sanitation and inadequate clean water supply are prevalent [20]. Globally, 700 million people are at risk with 240 million in 76 countries infected [21]. Human schistosomiasis is second only to malaria in mortality with an annual death of 200,000 people [22]. In Ethiopia, 5 million people are infected with schistosomiasis and 37.5 million are at risk of infection [23].

The purpose of this study is, therefore, to investigate the in vitro antileishmanial activity of fresh leaves of the plant against the promastigote and intracellular amastigote forms of L. aethiopica and L. donovani clinical isolates. The report further details antileishmanial and antischistosomal activity of the major compound isolated from the hydro-distilled extract of the fresh leaves of R. multifidus characterised as anemonin.

\section{Results and Discussion}

In the current study, fresh leaves of R. multifidus were used to prepare extracts in order to mimic the form in which the plant is used in traditional medicine. As the bioactive compounds present in the plant may vary in their polarity, two extraction methods were employed. Cold maceration with $80 \%$ methanol was used to extract heat-labile polar and moderately polar compounds, while hydro-distillation was employed to extract thermally stable and relatively non-polar components. Maceration with hydro-alcohol gave $6.4 \%$ $(w / w)$ of brown powder, while hydro-distillation yielded $0.56 \%(w / w)$ yellow coloured irritating oil.

Antileishmanial assay was done on L. aethiopica and L. donovani, which are the major causes of cutaneous leishmaniasis and visceral leishmaniasis in Ethiopia, respectively $[3,6,24]$. AlamarBlue ${ }^{\circledR}$ or resazurin (7-hydroxy-10-oxidophenoxazin-10-ium-3-one) reduction assay was used to determine the antileishmanial activity and cytotoxicity of the test substances as the technique permits a simple, rapid, reliable, sensitive, cost-effective method for continuous monitoring of cell cultures [25].

In both antileishmanial and cytotoxicity assays, a positive linear correlation was established between viability of cell and concentrations of test substances $\left(R^{2}=0.981-0.992\right)$. As shown in Table 1, both the hydro-alcoholic and hydro-distilled extracts displayed antileishmanial activity on both the promastigote and amastigote forms of L. aethiopica and L. donovani with $\mathrm{IC}_{50}$ values ranging from 0.49 to $22.12 \mu \mathrm{g} / \mathrm{mL}$. However, the hydro-distilled extract was found to be significantly $(p<0.001)$ more potent than the hydro-alcoholic extract. Thus, further phytochemical analysis of the former using preparative thin layer chromatog- 
raphy (PTLC) resulted in the isolation of the $\alpha, \beta$-unsaturated dilactone anemonin by the method described earlier [26]. The current study disclosed that anemonin possesses strong and comparable growth inhibitory effect against the promastigote and amastigote forms of L. aethiopica and L. donovani with antipromastigote $\mathrm{IC}_{50}$ values of $0.257 \mu \mathrm{g} / \mathrm{mL}(1.33 \mathrm{nM})$ and $0.303 \mu \mathrm{g} / \mathrm{mL}(1.58 \mathrm{nM})$, respectively. Anemonin also inhibited growth of the amastigote form of the parasites at nanomolar concentrations which were much lower than those of the extracts. However, amphotericin B was superior in its potency $(p<0.001)$ to that of anemonin against both the promastigote and amastigote forms of the tested parasites.

Table 1. In vitro antileishmanial activity of the fresh leaf extracts of Ranunculus multifidus and anemonin against promastigote and amastigote forms Leishmania aethiopica and Leishmania donovani.

\begin{tabular}{|c|c|c|c|c|}
\hline \multirow{3}{*}{ Test Substance } & \multicolumn{4}{|c|}{ Antileishmanial Activity $\mathrm{IC}_{50}(\mu \mathrm{g} / \mathrm{mL})$} \\
\hline & \multicolumn{2}{|c|}{ Promastigotes } & \multicolumn{2}{|c|}{ Amastigotes } \\
\hline & Leishmania aethiopica & Leishmania donovani & Leishmania aethiopica & Leishmania donovani \\
\hline RM-M & $14.92 \pm 0.554^{\mathrm{a} 1, \mathrm{~b} 1, \mathrm{c} 1}$ & $22.12 \pm 0.564^{\mathrm{a} 1, \mathrm{~b} 1, \mathrm{c} 1}$ & $17.487 \pm 0.298^{\mathrm{a} 1, \mathrm{~b} 1, \mathrm{c} 1}$ & $19.325 \pm 0.24$ a1,b1,c1 \\
\hline $\mathrm{RM}-\mathrm{H}$ & $0.49 \pm 0.004^{\mathrm{b} 1, \mathrm{c} 1}$ & $0.984 \pm 0.028^{\mathrm{b} 1, \mathrm{c} 1}$ & $1.49 \pm 0.004^{\mathrm{b} 1, \mathrm{c} 1}$ & $1.814 \pm 0.028^{\mathrm{b} 1, \mathrm{c} 1}$ \\
\hline Anemonin & $0.257 \pm 0.007(1.33)^{\mathrm{c} 1}$ & $0.303 \pm 0.304(1.58) \mathrm{c} 1$ & $0.239 \pm 0.014(1.24)^{\mathrm{c} 1}$ & $0.368 \pm 0.024(1.91)^{\mathrm{c} 1}$ \\
\hline AMB & $0.0157 \pm 0.08(0.017)$ & $0.0067 \pm 0.008(0.0072)$ & $0.0095 \pm 0.004(0.01)$ & $0.0063 \pm 0.011(0.0068)$ \\
\hline
\end{tabular}

Data expressed as mean \pm SEM; $n=3$; a: compared to RM-H, b: compared to anemonin, c: compared to Amphotericin B; $1: p<0.001$; RM-M: $80 \%$ methanol extract of R. multifidus, RM-H: hydro-distilled extract of R. multifidus; AMB: amphotericin B. Values in parenthesis indicate concentration in nanomolar (nM).

Even though promastigotes and amastigotes evidently vary in their bioenergetics, morphology, gene expression, protein phosphorylation and expression of membrane proteins which result in difference in their susceptibility to test substances [27-29], the test substances displayed similar activities against the promastigote and amastigote forms of the tested parasites.

In vitro macrophage cytotoxicity tests revealed that the hydro-alcoholic extract is relatively nontoxic compared to the hydro-distilled extract, anemonin or amphotericin B (Table 2). Haemolysis test also confirmed that the hydroalcoholic extract has a very high $\mathrm{LC}_{50}$ value $(>1000 \mu \mathrm{g} / \mathrm{mL}$ ) indicating its relative safety to red blood cells. Both the hydro-distilled extract and amphotericin B were found to be toxic to macrophages and caused red blood cells lysis at much lower concentrations. Overall, the hydro-alcoholic extract appeared to be less toxic than the hydro-distilled extract. This is congruent with previous studies that reported the aqueous and dichloromethane: methanol (1:1) extracts of $R$. multifidus do not have cytotoxic effect on methyl thiazolyl tetrazolium (MTT) cellular viability assay against the human embryonic kidney epithelial cell line $(104 \%$ cell growth at $100 \mu \mathrm{g} / \mathrm{mL}$ ) [30].

Table 2. In vitro macrophage cytotoxicity, hemolytic property and selectivity indices of the fresh leaf extracts of Ranunculus multifidus and anemonin.

\begin{tabular}{ccccc}
\hline \multirow{2}{*}{ Test Substance } & \multicolumn{2}{c}{ Cytotoxicity $(\mu \mathrm{g} / \mathbf{m L})$} & \multicolumn{2}{c}{ Selectivity Index } \\
\cline { 2 - 5 } & Macrophage $\left(\mathbf{C C}_{\mathbf{5 0}}\right)$ & Hemolysis $\left(\mathbf{L C}_{\mathbf{5 0}}\right)$ & Leishmania aethiopica & Leishmania donovani \\
\hline RM-M & $256.62 \pm 0.211^{\mathrm{a} 1, \mathrm{~b} 1, \mathrm{c} 1}$ & $>1000^{\mathrm{a} 1, \mathrm{~b} 1, \mathrm{c} 1}$ & $1^{\mathrm{a} 1, \mathrm{~b} 1, \mathrm{c} 1}$ & $13^{\mathrm{a} 1, \mathrm{c} 1}$ \\
$\mathrm{RM}-\mathrm{H}$ & $4.98 \pm 1.583^{\mathrm{b} 1, \mathrm{c} 1}$ & $25.68 \pm 0.07^{\mathrm{b} 1, \mathrm{c} 1}$ & $3^{\mathrm{b} 1, \mathrm{c} 1}$ & $3^{\mathrm{b} 1, \mathrm{c} 1}$ \\
Anemonin & $5.39 \pm 2.013(28.00)^{\mathrm{c} 1}$ & $91.00 \pm 0.298(473.95)^{\mathrm{c} 1}$ & $2^{\mathrm{c} 1}$ & $14^{\mathrm{c} 1}$ \\
AMB & $4.31 \pm 0.983^{(4.66)}$ & $47.25 \pm 0.54(51.13)$ & 453 & 684 \\
\hline
\end{tabular}

Data expressed as mean $\pm \mathrm{SEM} ; n=3$; a: compared to $\mathrm{RM}-\mathrm{H}$, b: compared to anemonin, c: compared to Amphotericin B; 1: $p<0.001$; RM-M: $80 \%$ methanol extract of R. multifidus, RM-H: hydro-distilled extract of R. multifidus; $\mathrm{CC}_{50}$ : concentration causing $50 \%$ cytotoxicity, $\mathrm{LC}_{50}$ : concentration causing 50\% lysis; AMB: amphotericin B. Values in parenthesis indicate concentration in nanomolar (nM).

The in vitro macrophage cytotoxicity assay indicated that anemonin and amphotericin B have comparable $\mathrm{CC}_{50}$ values of 5.39 and $4.31 \mu \mathrm{g} / \mathrm{mL}$, respectively. However, the selectivity indices of amphotericin B (453 and 684) were much higher than anemonin 
(22 and 14) against L. aethiopica and L. donovani, respectively (Table 2), indicating that amphotericin B exhibits more selective toxicity to the parasites than anemonin.

As shown in Table 3, the in vitro antischistosomal assay showed that NTS were more susceptible to anemonin than adult $S$. mansoni, revealing high activity at $10 \mu \mathrm{M}$ after $72 \mathrm{~h}$ of incubation.

Table 3. In vitro antischistosomal activity of anemonin against adult Schistosoma mansoni and newly transformed schistosomula (NTS).

\begin{tabular}{cccc}
\hline & NTS & NTS & Adult Schistosoma mansoni \\
\hline Test Substance & $\%$ activity $(72 \mathrm{~h}, 10 \mu \mathrm{M})$ & $\%$ activity $(72 \mathrm{~h}, 1 \mu \mathrm{M})$ & $\%$ activity $(72 \mathrm{~h}, 10 \mu \mathrm{M})$ \\
Anemonin & $93.75 \pm 2.1$ & $41.38 \pm 3.4$ & $48.95 \pm 2.0$ \\
\hline
\end{tabular}

Results of the present study suggest that anemonin might be responsible for the antileishmanial activity of the fresh leaves of $R$. multifidus. Several studies reported that anemonin possesses anti-inflammatory activity by different mechanisms of action [31-37]. There are also reports that anemonin exhibits antibacterial [38,39], wound healing [40], antioxidant [41] and neuroprotective [35] activities. Saidi et al. [40] reported that anemonin has potent wound healing activity making it a promising candidate as a therapeutic agent in tissue repairing processes.

Leishmaniasis is still one of the endemic and highly prevalent diseases in Ethiopia [42]. Most people in Ethiopia use traditional medicine for the treatment of cutaneous leishmaniasis and have no knowledge of modern medical treatment [2]. Even communities who have knowledge about modern medicine may not have access to healthcare service. This, coupled with the high costs of diagnosis and treatment, further enhances the spread of the disease and reinforce poverty [5]. In Ethiopia, people living in cutaneous leishmaniasis endemic areas are exposed to L. aethiopica infection, which leaves permanent scar causing disfigurement that results in social stigmatization [43-45]. Most cutaneous leishmaniasis patients seek folk medicine and the majority have the attitude that treatment from traditional healers is effective [46]. In different parts of Ethiopia, fresh leaves of $R$. multifidus are used for the treatment of cutaneous leishmaniasis (without leaving a scar) $[17,18]$ and various types of skin diseases $[13,47-50]$. The present work confirms that R. multifidus extracts have the capacity to control localized cutaneous leishmaniasis caused by L. aethiopica and visceral leishmaniasis induced by L. donovani. Furthermore, inhibition of proliferation of the leishmania parasites by anemonin justifies the traditional use of the leaves of R. multifidus for the treatment of cutaneous leishmaniasis.

Although the prevalence of schistosomiasis in Ethiopia may have decreased over time due to the strategic use of anthelmintics [51], the disruption of the health system due to COVID-19 may have increased the prevalence. The WHO recommended the postponement of all mass drug administration (MDA) programs, community-based surveys and active case finding activities in April 2020. Schistosomiasis and visceral leishmaniasis were among the diseases that will be most affected by the disruption of the programs against NTDs [52] Due to the potential rise in cases of schistosomiasis caused by disruption to control programs, the antischistosomal activity of anemonin was also investigated. Although the antischistosomal activity of anemonin may have been low compared to the antileishmanial activity, it shows the potential of the compound to have various antiparasitic activities.

\section{Materials and Methods}

\subsection{Plant Material}

Fresh leaves of R. multifidus were collected from Dorze village of Chencha woreda, Gamo zone (520 km southwest of Addis Ababa, Ethiopia), located in the Rift Valley above the west shore of Lake Abaya at $6^{\circ} 11^{\prime} 36^{\prime \prime} \mathrm{N}$ and $37^{\circ} 34^{\prime} 13^{\prime \prime} \mathrm{E}$. The plant material was authenticated by Ato Melaku Wondafrash, National Herbarium, Department of Biology, 
College of Natural and Computational Sciences, Addis Ababa University (AAU), where a voucher specimen was deposited (collection number BS-001) for future reference.

\subsection{Chemicals and Reagents}

The chemicals and reagents used for the experiment include methanol (Cheshire, UK), Amphotericin B (Laborchemikalien GmbH, Germany), Giemsa (ESJAY Chemicals, Maharashtra, India), resazurin sodium salt, dimethyl sulfoxide (DMSO), triton X-114, potato starch powder (Sigma-Aldrich Laborchemikalien GmbH, Germany), phosphate buffer saline (PBS) (Gibco, Waltham, MA, USA), Roswell Park Memorial Institute-1640 (RPMI-1640) (Sigma-Aldrich, Gillingham, UK), minimum essential medium (MEM) (SigmaAldrich Co., St. Louis, MO, USA), heat inactivated new born calf serum (HINBCS) (SigmaAldrich Co., St. Louis, MO, USA) and penicillin-streptomycin solution (Sigma-Aldrich Co., St. Louis, MO, USA).

\subsection{Experimental Animals and Parasites}

Swiss albino mice were obtained from the animal house of the Department of Pharmacology (DoP), School of Pharmacy (SoP), College of Health Sciences (CHS), AAU. Mice of either sex weighing 22-30 $\mathrm{g}$ and age 5-6 weeks were employed. The animals were held in stainless steel cages at room temperature $\left(20-22^{\circ} \mathrm{C}\right)$ and a $12 \mathrm{~h}$ light $/ 12 \mathrm{~h}$ dark cycle. They were provided with water and food pellets ad libitum in the animal house of the DoP, SoP, $\mathrm{CHS}$, AAU. All the experiments were conducted in accordance with the internationally accepted laboratory animal use and care guideline [53] and were approved by the Institutional Review Board of the SoP, AAU (Approval code: ERB/SOP241b/13/2021). Clinical isolates of L. aethiopica $(306 / 17)$ and L. donovani $(139 / 19)$ were obtained from Leishmaniasis Research and Diagnostic Laboratory (LRDL), at the Department of Microbiology, Immunology and Parasitology, CHS, School of Medicine (SoM), AAU. The life cycle of Schistosoma mansoni is maintained at the Swiss Tropical and Public Health Institute (Swiss TPH).

\subsection{Extraction and Isolation}

Fresh leaves of R. multifidus were extracted by maceration using $80 \%$ methanol to obtain RM-M, and the hydro-distilled extract (RM-H) was prepared by hydro-distillation using Clevenger apparatus. Preparative TLC was used to isolate the major compound from the hydro-distilled extract. We obtained about $4 \mathrm{~g}$ of anemonin from $1 \mathrm{~kg}$ of fresh plant material. Extraction of anemonin has been reported previously by another method [54]. The characterization of the compound was achieved by means of spectroscopic techniques as described previously [26].

\subsection{Antileishmanial Assay}

\subsubsection{Leishmania Culture}

Clinically isolated L. aethiopica and L. donovani parasites were cultured in Lock's treated Novy-MacNeal-Nicolle (NNN) medium containing antibiotic solution (penicillin $100 \mathrm{IU} / \mathrm{mL}$ and streptomycin $100 \mu \mathrm{g} / \mathrm{mL}$ ) [55]. The logarithmic stage parasites were transferred from NNN media into tissue culture flasks containing complete rpmI-1640 medium (RPMI-1640 medium supplemented with $10 \%$ heat inactivated foetal calf serum (HIFCS) and $100 \mathrm{IU}$ penicillin/mL and $100 \mu \mathrm{g} / \mathrm{mL}$ streptomycin solution) at $22{ }^{\circ} \mathrm{C}$ for L. aethiopica and $26^{\circ} \mathrm{C}$ for L. donovani $[56,57]$. The culture was monitored every day for two weeks to ensure healthy growth of parasites [58]. The logarithmic stage of the parasites was used for antipromastigote assay, while the stationary phase (metacyclic phase) was used for macrophage infection (antiamastigote assay) [55].

\subsubsection{Antipromastigotes Assay}

To 96-well plates filled with $100 \mu \mathrm{L}$ of complete rpmI-1640 medium, $100 \mu \mathrm{L}$ of test substance $(300 \mu \mathrm{g} / \mathrm{mL})$ dissolved in $3 \%$ DMSO was added on the first well. Then, $100 \mu \mathrm{L}$ was taken into subsequent wells then the last $100 \mu \mathrm{L}$ was discarded, to achieve three-fold 
serial dilution. A total of 12 dilutions ranging from $100 \mu \mathrm{g} / \mathrm{mL}$ up to $0.000565 \mu \mathrm{g} / \mathrm{mL}$ were made to establish a full dose titration and determine $\mathrm{IC}_{50}$ values. All dilutions were done carefully by avoiding bubble formation. DMSO $<1 \%$ was used as a negative control (this concentration was used to prevent its negative outcome in cell viability), and amphotericin $\mathrm{B}$ was used as a positive control (same serial dilution as the test substances) [59]. Then, $100 \mu \mathrm{L}$ of suspension of logarithmic stage of the parasites $\left(1 \times 10^{6}\right.$ promastigotes $/ \mathrm{mL}$ of L. aethiopica or L. donovani) were added to each well and contents of the plates were incubated at $22{ }^{\circ} \mathrm{C}$ for L. aethiopica and $26^{\circ} \mathrm{C}$ for L. donovani [58]. After $68 \mathrm{~h}$ of incubation $2 \mu \mathrm{L}$ of fluorochrome resazurin solution (12.5 mg AlamarBlue dissolved in $100 \mathrm{~mL}$ of PBS) were added and incubated accordingly for $4 \mathrm{~h}$ for a total of $72 \mathrm{~h}$ [60]. The fluorescence intensity was then measured by microplate fluorometer and luminometer at excitation wavelength of $530 \mathrm{~nm}$ and emission wavelength of $590 \mathrm{~nm}$ [60]. The background fluorescence intensity of the complete media, samples and reference drug was measured and subtracted for the corresponding wells.

\subsubsection{Intra-Peritoneal Macrophage Collection and Culture}

Macrophages were collected from mice first by disinfecting the skin around the peritoneum with $70 \%$ ethanol and a mouse was injected with $1 \mathrm{~mL}$ of freshly prepared $2 \%$ starch intraperitoneally [61]. After four days, the mice were sacrificed by spinal dislocation and the skin underlying the peritoneal cavity was shaved aseptically to expose the intact peritoneum. Then $10 \mathrm{~mL}$ of sterile ice-cold phosphate buffered saline (PBS) with $3 \%$ HINBCS were injected into the peritoneal cavity and the peritoneal wall was massaged carefully to dislodge the attached macrophages [62]. Macrophages were then collected by drawing 6-8 $\mathrm{mL}$ of exudates which were transferred into sterile $15 \mathrm{~mL}$ test tubes and centrifuged at $3500 \mathrm{rpm}$ for $10 \mathrm{~min}$ at $4{ }^{\circ} \mathrm{C}$. A portion of the resulting pellet was cultured in 96-well plates containing $1 \times 10^{4}$ macrophage suspended in complete rpmI-1640 medium and kept for macrophage cytotoxicity assay [63].

\subsubsection{Antiamastigotes Assay}

A portion of macrophages were suspended in complete MEM media containing 10\% HINBCS, $2 \mathrm{mM}$ L-glutamine, $100 \mathrm{IU}$ penicillin and $100 \mu \mathrm{g}$ streptomycin $/ \mathrm{mL}$. The host cells (macrophage) were counted and adjusted accordingly using a haemocytometer to $1 \times 10^{6}$ cells per $\mathrm{mL}$ in complete MEM media. Then $300 \mu \mathrm{L}\left(3 \times 10^{5}\right.$ macrophages $)$ were seeded in every well of an 8-well plate containing removable microscopic slides. The cultured macrophage cells were allowed for adherence for at least $12 \mathrm{~h}$ at $37^{\circ} \mathrm{C}$ in $5 \% \mathrm{CO}_{2}$. Non-adherent cells were washed twice with pre-warmed complete MEM media and incubated overnight in fresh media [64]. Following overnight incubation, adherent cells were infected separately with late stationary stage $L$. aethiopica and $L$. donovani promastigotes with a parasite-to-cell ratio of 10:1 and incubated further for $12 \mathrm{~h}$. After removal of non-internalized promastigotes by extensive washing with complete MEM

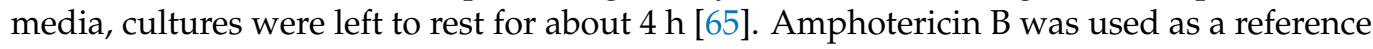
drug to check sensitivity of the parasites. Samples were serially diluted in 8-well plates as indicated in the antipromastigote assay. The prepared macrophage culture was incubated with or without $100 \mu \mathrm{L}$ of test substance for three days at $31^{\circ} \mathrm{C}$ (L. aethiopica) and $37^{\circ} \mathrm{C}$ (L. donovani), $5 \% \mathrm{CO}_{2}$ and $95 \%$ relative humidity. Following $72 \mathrm{~h}$ of incubation, the media was discarded, the slides were washed with PBS (prewarmed at $37^{\circ} \mathrm{C}$ ) and methanol was used for fixation for $15 \mathrm{~min}$; then the slides were stained with $10 \%$ Giemsa for $15 \mathrm{~min}$ and washed with distilled water. The slides were then observed under microscope with oil immersion ( $100 \times$ objective). The number of amastigotes was determined by counting amastigotes in at least 50 macrophages in duplicate cultures [65]. Antiamastigote activity was determined by assessing the infection rate and parasitic load in both treated and untreated groups. Infection was considered adequate if more than $70 \%$ of the macrophages 
present in the negative control were infected. The total actual parasite burdens were calculated using the infection index shown below [66].

$$
\text { \%Infection index }=\frac{\text { No of infected macrophage }}{\text { Total macrophage counted }} \times \frac{\text { No of amastigotes in } 50 \text { infected macrophages }}{\text { Total macrophage counted }}
$$

The first half of the equation gives the percentage of infected macrophages and the second gives average parasite load found in infected macrophages [67]. The $\mathrm{IC}_{50}$ is inhibitory concentration of the test substance that reduces $50 \%$ amastigotes density [68].

\subsubsection{Macrophage Cytotoxicity Assay}

Macrophage cells were cultured in complete rpmI-1640 media, humidified $5 \% \mathrm{CO}_{2}$ and incubated at $37^{\circ} \mathrm{C}$ for $24 \mathrm{~h}$ [62]. In 96-well plates containing a pre-cultured $100 \mu \mathrm{L}$ suspensions of $1 \times 10^{4}$ macrophage, the medium was replaced by $100 \mu \mathrm{L}$ of serially diluted test substances. A total of 12 dilutions $(1000 \mu \mathrm{g} / \mathrm{mL}-0.00565 \mu \mathrm{g} / \mathrm{mL})$ dissolved in $1 \%$ DMSO were made [64]. Then contents of the plates were incubated at $37^{\circ} \mathrm{C}$ in $5 \% \mathrm{CO}_{2}$. After $48 \mathrm{~h}$ of incubation, $5 \mu \mathrm{L}(1 / 20, v / v)$ fluorochrome resazurin solution was added into each well and the fluorescence intensity was measured after $3 \mathrm{~h}$ using microplate fluorometer and luminometer at excitation wavelength of $530 \mathrm{~nm}$ and emission wavelength of $590 \mathrm{~nm}$ [69]. The concentration which kills $50 \%$ of the cells for each test substance $\left(\mathrm{CC}_{50}\right)$ was calculated [68].

\subsubsection{Selectivity Index}

Selectivity index (SI) was determined using $\mathrm{CC}_{50}$ of the normal macrophage and the $\mathrm{IC}_{50}$ of amastigotes. The selectivity of the test substance in killing the parasites as opposed to mice macrophage cells was assessed by the following formula [63]:

$$
\text { Selectivity index }(\mathrm{SI})=\frac{\mathrm{CC}_{50} \text { macrophage }}{\mathrm{IC}_{50} \text { amastigote }}
$$

\subsection{Hemolysis Assay}

Hemolytic activity was determined by using red blood cells (RBCs) prepared from freshly collected $\mathrm{O}^{+}$human blood $(2 \mathrm{~mL})$ added to $48 \mathrm{~mL}$ of PBS and centrifuged at $3500 \mathrm{rpm}$ for $10 \mathrm{~min}$ at $4{ }^{\circ} \mathrm{C}$. The supernatant was washed off $(3 \times)$ with PBS resulting in the formation of approximately $1 \mathrm{~mL}$ of RBC pellets [70]. The resulting pellet was then re-suspended in $49 \mathrm{~mL}$ of PBS to make $2 \%$ blood suspension and the concentration adjusted to $1.9 \times 10^{9} \mathrm{RBC} / \mathrm{mL}$. Then, $200 \mu \mathrm{L}$ of the blood suspension was pipetted into Eppendorf tubes containing each test substance at concentrations of 3.7, 11.11, 33.33, 100, 300 , and $900 \mu \mathrm{g} / \mathrm{mL}$ to give a final volume of $1500 \mu \mathrm{L}$ [71]. The suspension containing $2.5 \times 10^{8} \mathrm{RBC} / \mathrm{mL}$ was carefully mixed and incubated at $37^{\circ} \mathrm{C}$ for $2 \mathrm{~h}$. The membrane destabilizing activity of each test substance was determined in terms of its capability to rupture the cell membranes of RBC letting the release of hemoglobin into the solution. The mixture was centrifuged at $3500 \mathrm{rpm}$ for $10 \mathrm{~min}$ resulting in intact and ruptured RBC to pellet liberating the hemoglobin in the supernatant solution, and $75 \mu \mathrm{L}$ from the supernatant of each tube was collected in 96-well plates; absorbance was measured at $540 \mathrm{~nm}$ using a Lambda 9 spectrophotometer (Perkin Elmer, UK) [72]. Triton X-114 $(5 \mu \mathrm{L} / \mathrm{mL})$ was used as a positive control, and was prepared by adding $50 \mu \mathrm{L}$ of blood to $100 \mu \mathrm{L}$ Triton X-114 and incubated at $37^{\circ} \mathrm{C}$ for $30 \mathrm{~min}$ [73]. RBC suspension with $1 \%$ DMSO was used as a negative control. Hemolytic effects were expressed as percentage of the absorbance of the positive control $(100 \%)$ and the $50 \%$ lytic concentrations $\left(\mathrm{LC}_{50}\right)[72,74,75]$.

\subsection{Antischistosomal Assays}

In vitro studies were carried out in accordance with Swiss national and cantonal regulations on animal welfare under the permission number 2070. The drug sensitivity assays with Schistosoma mansoni (adult and newly transformed schistosomules (NTS)) were carried out as described recently [76]. Briefly, to obtain NTS, cercariae were collected from 
infected Biomphalaria glabrata snails and were mechanically transformed. Adult S. mansoni worms were collected by dissecting the mesenteric veins of infected mice at day 49 postinfection. Approximately 30-40 NTS were incubated with the respective test drug in $250 \mu \mathrm{L}$ of M199 medium (Gibco, Waltham, MA, USA) supplemented with $5 \%(v / v)$ foetal calf serum (FCS) (Bioconcept AG, Switzerland), 1\% $(v / v)$ penicillin/streptomycin solution (Sigma-Aldrich, Switzerland) and 1\% $(v / v)$ antibacterial/antifungal solution for up to $72 \mathrm{~h}$ at $37{ }^{\circ} \mathrm{C}$ and $5 \% \mathrm{CO}_{2}$. The drug was tested at 10 and $1 \mu \mathrm{M}$ in triplicate and repeated once. Three adult $S$. mansoni were incubated in a final volume of $2 \mathrm{~mL} \mathrm{rpmI} 1640$ supplemented with $5 \%(v / v)$ FCS and $1 \%(v / v)$ penicillin/streptomycin at $37^{\circ} \mathrm{C}$ and $5 \% \mathrm{CO}_{2}$ for $72 \mathrm{~h}$ at $10 \mu \mathrm{M}$. The experiment was conducted in duplicate.

Worms were judged via microscopic readout $72 \mathrm{~h}$ after incubation; they were scored according to phenotypic reference points such as motility, morphology and granularity (scores from 0 to 3 ).

\subsection{Statistical Analysis}

The antileishmanial, macrophage cytotoxicity and haemolysis assays were done in triplicate experiments with each test concentration in duplicate. The respective $\mathrm{IC}_{50}, \mathrm{CC}_{50}$ and $\mathrm{LC}_{50}$ values for each test substance were determined by non-linear regression analysis from sigmoidal dose-response curves using computer software GraphPad prism 8.0 and values were expressed as mean \pm standard error of mean (SEM). Statistical significance was determined by one-way ANOVA followed by Tukey post hoc test to compare different parameters among the treatment and control groups. $P<0.05$ was considered significant.

\section{Conclusions}

In conclusion, the results of the present study revealed that the fresh leaf extracts of R. multifidus display potent in vitro antileishmanial activity which justify the traditional use of the plant for the treatment of leishmaniasis. The finding also suggests that anemonin is likely responsible for the leishmanicidal activity of the plant. Anemonin also showed high antischistosomal activity against NTS and moderate activity against adult S. mansoni. To the best of our knowledge, this is the first study that reports the antileishmanial activity of R. multifidus and its major compound anemonin as well as the antischistosomal activity of anemonin. The promising activity of anemonin shown in this study warrants its potential as a lead compound for the development of safer, more potent and cost- effective alternative drugs for the treatment of leishmaniasis and schistosomiasis. Previously, we had shown that alkaline hydrolysis of anemonin results in the formation a dicarboxylate [26]. Therefore, one possibility is to use this hydrophilic anemonin derivative as a starting material and template for the synthesis of antileishmanial compounds. The formulation of anemonin in anti-inflammatory preparations gives indications as to how this lipophilic compound can be administered orally [77].

Author Contributions: Conceptualization, B.S., K.A. and P.I.; methodology, B.S., K.A., A.H., C.H. and J.K.; writing—original draft preparation, B.S.; writing—review and editing, K.A., J.K., M.D., N.A. and P.I.; supervision, K.A. and P.I.; project administration, K.A. and P.I.; funding acquisition, B.S., K.A. and P.I. All authors have read and agreed to the published version of the manuscript.

Funding: This study was supported by the School of Graduate Studies of Addis Ababa University research grant. It was also was supported by the TRISUSTAIN project (https: / trisustain.uni-halle.de/) "Economic, ecological and therapeutic sustainability in the development of phytopharmaceuticals for Sub-Saharan Africa" and the PhytoWoodSynergies project, both funded by the Federal Ministry of Education and Research (BMBF grant numbers 01DG17008B and 01DG17042B), and by the German Academic Exchange Service (DAAD grant number. 57369155 and grant number 57566179). J.K. is grateful to the Swiss National Science Foundation for financial support (No. 320030_175585).

Institutional Review Board Statement: All the animal study procedures followed were reviewed and approved by the Institutional Review Board of the SoP, CHS, AAU. The mice were handled in accordance with the Guide for the Care and Use of Laboratory Animals [53]. 
Data Availability Statement: The authors declare that all data supporting the finding of this study are included in this article.

Acknowledgments: One of the authors (B.S.) would like to acknowledge Addis Ababa University, School of Graduate Studies, for the research grant as well as Arba Minch University for sponsoring. The authors would like to express their gratitude to the Deutsche Forschungsgemeinschaft for partly funding the research work and Melaku Wondafrash of the National Herbarium, AAU, for authenticating the plant material. We acknowledge the financial support of the Open Access Publication Fund of the Martin-Luther-University Halle-Wittenberg.

Conflicts of Interest: The authors declare no conflict of interest.

Sample Availability: Samples of the compound are available from the authors.

\section{References}

1. World Health Organization. Leishmaniasis; WHO: Geneva, Switzerland, 2021. Available online: https://www.who.int/newsroom/fact-sheets / detail/leishmaniasis (accessed on 28 September 2021).

2. Bsrat, A.; Berhe, N.; Balkew, M.; Yohannes, M.; Teklu, T.; Gadisa, E.; Medhin, G.; Abera, A. Epidemiological study of cutaneous leishmaniasis in Saesie Tsaeda-emba district, eastern Tigray, northern Ethiopia. Parasit. Vectors 2015, 8, 149. [CrossRef] [PubMed]

3. Gadisa, E.; Tsegaw, T.; Abera, A.; Elnaiem, D.E.; Den Boer, M.; Aseffa, A.; Jorge, A. Eco-epidemiology of visceral leishmaniasis in Ethiopia. Parasit. Vectors 2015, 8, 381. [CrossRef]

4. Seid, A.; Gadisa, E.; Tsegaw, T.; Abera, A.; Teshome, A.; Mulugeta, A.; Herrero, M.; Argaw, D.; Jorge, A.; Kebede, A.; et al. Risk map for cutaneous leishmaniasis in Ethiopia based on environmental factors as revealed by geographical information systems and statistics. Geospat. Health 2014, 8, 377-387. [CrossRef] [PubMed]

5. Alvar, J.; Aparicio, P.; Aseffa, A.; Den Boer, M.; Canavate, C.; Dedet, J.P.; Gradoni, L.; Ter Horst, R.; López-Vélez, R.; Moreno, J. The relationship between leishmaniasis and AIDS: The second 10 years. Clin. Microbiol. Rev. 2008, 21, 334-359. [CrossRef] [PubMed]

6. Lemma, A.; Foster, W.A.; Gemetchu, T.; Preston, P.M.; Bryceson, A.; Minter, D.M. Studies on leishmaniasis in Ethiopia: I. Preliminary investigations into the epidemiology of cutaneous leishmaniasis in the highlands. Ann. Trop. Med. Parasit. 1969, 63, 455-472. [CrossRef]

7. Bryceson, A.A. Policy for leishmaniasis with respect to the prevention and control of drug resistance. Trop. Med. Int. Health 2001, 6, 928-934. [CrossRef] [PubMed]

8. Capela, R.; Moreira, R.; Lopes, F. An overview of drug resistance in protozoal diseases. Int. J. Mol. Sci. 2019, 20, 5748. [CrossRef]

9. Deep, D.K.; Singh, R.; Bhandari, V.; Verma, A.; Sharma, V.; Wajid, S.; Sundar, S.; Ramesh, V.; Dujardin, J.C.; Salotra, P. Increased miltefosine tolerance in clinical isolates of Leishmania donovani is associated with reduced drug accumulation, increased infectivity and resistance to oxidative stress. PLoS Negl. Trop. Dis. 2017, 11, e0005641. [CrossRef] [PubMed]

10. Mutiso, J.M.; Macharia, J.C.; Kiio, M.N.; Ichagichu, J.M.; Rikoi, H.; Gicheru, M.M. Development of leishmania vaccines: Predicting the future from past and present experience. J. Biomed. Res. 2013, 27, 85-102. [PubMed]

11. Okwor, I.; Uzonna, J. Vaccines and vaccination strategies against human cutaneous leishmaniasis. Hum. Vaccin. 2009, 5, 291-301. [CrossRef]

12. Chunge, C.N.; Gacmra, G.; Muigai, R.; Wasunna, K.; Rashid, J.R.; Chulay, J.D.; Anabwani, G.; Oster, C.N.; Bryceson, A.D.M. Visceral leishmaniasis unresponsive to antimonial drugs III. Successful treatment using a combination of sodium stibogluconate plus allopurinol. Trans. R. Soc. Trop. Med. Hyg. 1985, 79, 715-718. [CrossRef]

13. Teklehaymanot, T.; Giday, M.; Medhin, G.; Mekonnen, Y. Knowledge and use of medicinal plants by people around Debre Libanos monastery in Ethiopia. J. Ethnopharmacol. 2007, 111, 271-283. [CrossRef] [PubMed]

14. Hedberg, I. Medicinal and poisonous plants of the tropics. In Proceedings of the Symposium 5-35 of the 14th International Botanical Congress, Berlin, Germany, 24 July-1 August 1987; Leeuwenberg, A.J.M., Ed.; Pudoc: Wageningen, The Netherlands, 1987; Volume 6, pp. 9-15.

15. Teketay, D. Ranunculaceae. In The Flora of Ethiopia and Eritrea. Magnoliaceae to Flacourtiaceae; Edwards, S., Tadesse, M., Demissew, S., Hedberg, I., Eds.; National Herbarium: Addis Ababa, Ethiopia, 1993; Volume 2, pp. 18-32.

16. Yineger, H.; Kelbessa, E.; Bekele, T.; Lulekal, E. Plants used in traditional management of human ailments at Bale Mountains National Park, Southeastern Ethiopia. J. Med. Plants Res. 2008, 2, 132-153.

17. Aschale, Y.; Wubetu, M.; Reta, H. Ethnobotany of medicinal plants used to treat leishmaniasis in Ethiopia: A systematic review. J. Tradit. Med. Clin. Naturop. 2018, 7, 271. [CrossRef]

18. Birhan, Y.S.; Kitaw, S.L.; Alemayehu, Y.A.; Mengesha, N.M. Ethnobotanical study of medicinal plants used to treat human diseases in Enarj Enawga district, East Gojjam zone, Amhara region, Ethiopia. SM J. Med. Plant. Stud. 2017, 1, 1006.

19. Fostok, S.F.; Ezzeddine, R.A.; Homaidan, F.R.; Al-Saghir, J.A.; Salloum, R.G.; Saliba, N.A.; Talhouk, R.S. Interleukin-6 and cyclooxygenase-2 downregulation by fatty-acid fractions of Ranunculus constantinopolitanus. BMC Complement. Altern. Med. 2009, 9, 44. [CrossRef] [PubMed] 
20. Hussen, S.; Assegu, D.; Tadesse, B.T.; Shimelis, T. Prevalence of Schistosoma mansoni infection in Ethiopia: A systematic review and meta-analysis. Trop. Dis. Travel. Med. Vaccines 2021, 7, 4. [CrossRef] [PubMed]

21. Sady, H.; Al-Mekhlafi, H.M.; Mahdy, M.A.K.; Lim, Y.A.L.; Mahmud, R.; Surin, J. Prevalence and associated factors of schistosomiasis among children in Yemen: Implications for an effective control programme. PLoS Negl. Trop. Dis. 2013, 7, e2377. [CrossRef] [PubMed]

22. World Health Organization. Schistosomiasis: Key Facts; WHO: Geneva, Switzerland, 2021. Available online: https://www.who. int/news-room/fact-sheets / detail/schistosomiasis (accessed on 15 September 2021).

23. Steinmann, P.; Keiser, J.; Bos, R.; Tanner, M.; Utzinger, J. Schistosomiasis and water resources development: Systematic review, meta-analysis, and estimates of people at risk. Lancet Infect. Dis. 2006, 6, 411-425. [CrossRef]

24. Ashford, R.W.; Bray, M.A.; Hutchinson, M.P.; Bray, R.S. The epidemiology of cutaneous leishmaniasis in Ethiopia. Trans. R. Soc. Trop. Med. Hyg. 1973, 67, 568-601. [CrossRef]

25. Hoet, S.; Opperdoes, F.; Brun, R.; Adjakidjé, V.; Quetin-Leclercq, J. In vitro antitrypanosomal activity of ethnopharmacologically selected Beninese plants. J. Ethnopharmacol. 2004, 91, 37-42. [CrossRef]

26. Sirak, B.; Mann, L.; Richter, A.; Asres, K.; Imming, P. In vivo antimalarial activity of leaf extracts and a major compound isolated from Ranunculus multifidus Forsk. Molecules 2021, 26, 6179. [CrossRef]

27. Handman, E. Cell biology of Leishmania. Adv. Parasitol. 1999, 44, 1-39. [PubMed]

28. Callahan, H.L.; Portal, A.C.; Devereaux, R.; Grogl, M. An axenic amastigote system for drug screening. Antimicrob. Agents Chemother. 1997, 41, 818-822. [CrossRef]

29. Glew, R.H.; Saha, A.K.; Das, S.; Remaley, A.T. Biochemistry of the Leishmania species. Microbiol. Rev. 1988, 52, 412-432. [CrossRef] [PubMed]

30. Naidoo, D.; van Vuuren, S.F.; van Zyl, R.L.; De Wet, H. Plants traditionally used individually and in combination to treat sexually transmitted infections in northern Maputaland, South Africa: Antimicrobial activity and cytotoxicity. J. Ethnopharmacol. 2013, 149, 656-667. [CrossRef] [PubMed]

31. Hou, H.; Peng, Q.; Wang, S.; Zhang, Y.; Cao, J.; Deng, Y.; Wang, Y.; Sun, W.C.; Wang, H.B. Anemonin attenuates RANKL-induced osteoclastogenesis and ameliorates LPS-induced inflammatory bone loss in mice via modulation of NFATc1. Front. Pharmacol. 2020, 10, 1696. [CrossRef] [PubMed]

32. Wang, Z.; Huang, J.; Zhou, S.; Luo, F.; Xu, W.; Wang, Q.; Tan, Q.; Chen, L.; Wang, J.; Chen, H.; et al. Anemonin attenuates osteoarthritis progression through inhibiting the activation of IL-1ß/NF-kB pathway. J. Cell Mol. Med. 2017, 21, 3231-3243. [CrossRef] [PubMed]

33. Xiao, K.; Cao, S.T.; Jiao, L.F.; Lin, F.H.; Wang, L.; Hu, C.H. Anemonin improves intestinal barrier restoration and influences TGF- $\beta 1$ and EGFR signaling pathways in LPS-challenged piglets. Innate Immun. 2016, 22, 344-352. [CrossRef] [PubMed]

34. Ning, Y.; Rao, Y.; Yu, Z.; Liang, W.; Li, F. Skin permeation profile and anti-inflammatory effect of anemonin extracted from weilingxian. J. Pharm. Sci. 2016, 71, 134-138.

35. Jia, D.; Han, B.; Yang, S.; Zhao, J. Anemonin alleviates nerve injury after cerebral ischemia and reperfusion (i/r) in rats by improving antioxidant activities and inhibiting apoptosis pathway. J. Mol. Neurosci. 2014, 53, 271-279. [CrossRef]

36. Lee, T.H.; Huang, N.K.; Lai, T.C.; Yang, A.T.; Wang, G.J. Anemonin, from Clematis crassifolia, potent and selective inducible nitric oxide synthase inhibitor. J. Ethnopharmacol. 2008, 116, 518-527. [CrossRef]

37. Duan, H.; Zhang, Y.; Xu, J.; Qiao, J.; Suo, Z.; Hu, G.; Mu, X. Effect of anemonin on NO, ET-1 and ICAM-1 production in rat intestinal microvascular endothelial cells. J. Ethnopharmacol. 2006, 104, 362-366. [CrossRef] [PubMed]

38. Nazir, S.; Li, B.; Tahir, K.; Khan, A.; Khan, Z.U.H.; Khan, S. Antimicrobial activity of five constituents isolated from Ranunculus muricatus. J. Med. Plants Res. 2013, 7, 3438-3443.

39. Baer, H.; Holden, M.; Seegal, B.C. The nature of the antibacterial agent from Anemone pulsatilla. J. Biol. Chem. 1946, 162, 65-68. [CrossRef]

40. Saidi, R.; Ghrab, F.; Kallel, R.; El Feki, A.; Boudawara, T.; Chesné, C.; Ammar, E.; Jarraya, R.M. Tunisian Clematis flammula essential oil enhances wound healing: GC-MS analysis, biochemical and histological assessment. J. Oleo Sci. 2018, 67, 1483-1499. [CrossRef] [PubMed]

41. Qiao, L.; Liu, Y.; Li, C.; Ge, J.; Li, T. Regulation of irhom-2/tumor necrosis factor- $\alpha$ converting enzyme pathway and oxidative stress protects the renal injury with anemonin in streptozotocin-induced diabetic nephropathy neonatal rat model. Pharmacology 2019, 104, 258-266. [CrossRef] [PubMed]

42. Assefa, A. Leishmaniasis in Ethiopia: A systematic review and meta-analysis of prevalence in animals and humans. Heliyon 2018, 4, e00723. [CrossRef] [PubMed]

43. van Henten, S.; Adriaensen, W.; Fikre, H.; Akuffo, H.; Diro, E.; Hailu, A.; van der Auwera, G.; van Griensven, J. Cutaneous leishmaniasis due to Leishmania aethiopica. Clin. Med. 2018, 6, 69-81. [CrossRef]

44. Bugssa, G.; Hailu, A.; Demtsu, B. The current status of cutaneous leishmaniasis and the pattern of lesions in Ochollo primary school students, Ochollo, Southwestern Ethiopia. Sci. J. Clin. Med. 2014, 3, 111-116. [CrossRef]

45. Negera, E.; Gadisa, E.; Yamuah, L.; Engers, H.; Hussein, J.; Kuru, T.; Hailu, A.; Gedamu, L.; Aseffa, A. Outbreak of cutaneous leishmaniasis in Silti woreda, Ethiopia: Risk factor assessment and causative agent identification. Trans. R. Soc. Trop. Med. Hyg. 2008, 102, 883-890. [CrossRef] 
46. Kebede, N.; Worku, A.; Ali, A.; Animut, A.; Negash, Y.; Gebreyes, W.A.; Satoskar, A. Community knowledge, attitude and practice towards cutaneous leishmaniasis endemic area Ochello, Gamo Gofa Zone, South Ethiopia. Asian Pac. J. Trop. Biomed. 2016, 6, 562-567. [CrossRef]

47. Ayele, T.T. A review on traditionally used medicinal plants/herbs for cancer therapy in Ethiopia: Current status, challenge and future perspectives. Org. Chem. Curr. Res. 2018, 7, 2. [CrossRef]

48. Abebe, W. An overview of Ethiopian traditional medicinal plants used for cancer treatment. Eur. J. Med. Plants 2016, 14, 1-16. [CrossRef]

49. Awas, T.; Demissew, S. Ethnobotanical study of medicinal plants in Kafficho people, southwestern Ethiopia. In Proceedings of the 16th International Conference of Ethiopian Studies; NTNU-Trykk Press: Trondheim, Norway, 2009; Volume 3, pp. 3711-3726.

50. Giday, M.; Asfaw, Z.; Woldu, Z. Medicinal plants of the Meinit ethnic group of Ethiopia: An ethnobotanical study. J. Ethnopharmacol. 2009, 124, 513-521. [CrossRef] [PubMed]

51. Maddren, R.; Phillips, A.; Ower, A.; Landeryou, T.; Mengistu, B.; Anjulo, U.; Firdawek, E.; Negussu, N.; Anderson, R. Soiltransmitted helminths and schistosome infections in Ethiopia: A systematic review of progress in their control over the past 20 years. Parasit. Vectors 2021, 14, 97. [CrossRef] [PubMed]

52. Brooker, S.J.; Ziumbe, K.; Negussu, N.; Crowley, S.; Hammami, M. Neglected tropical disease control in a world with COVID-19: An opportunity and a necessity for innovation. Trans. R. Soc. Trop. Med. Hyg. 2021, 115, 205-207. [CrossRef] [PubMed]

53. Institute for Laboratory Animal Research (ILAR). Guide for the Care and Use of Laboratory Animals; The National Academy Press: Washington, DC, USA, 1996.

54. Fang, X.; Liu, J.; Yang, L.; Li, X. Study on the optimization of extraction technology of anemonin from Pulsatilla chinensis and its inhibitory effect on Alternaria panax. J. Dis. Med. Plants 2019, 5, 94-102.

55. Tegazzini, D.; Díaz, R.; Aguilar, F.; Peña, I.; Presa, J.L.; Yardley, V.; Martin, J.J.; Coteron, J.M.; Croft, S.L.; Cantizani, J. A replicative in vitro assay for drug discovery against Leishmania donovani. Antimicrob. Agents Chemother. 2016, 60, 3524-3532. [CrossRef] [PubMed]

56. Habtemariam, S. In vitro antileishmanial effects of antibacterial diterpenes from two Ethiopian Premna species: P. schimperi and P. oligotricha. BMC Pharmacol. 2003, 3, 6. [CrossRef] [PubMed]

57. Ephros, M.; Bitnun, A.; Shaked, P.; Waldman, E.; Zilberstein, D. Stage-specific activity of pentavalent antimony against Leishmania donovani axenic amastigotes. Antimicrob. Agents Chemother. 1999, 43, 278-282. [CrossRef] [PubMed]

58. Castilla, J.J.; Sanchez-Moreno, M.; Mesa, C.; Osuna, A. Leishmania donovani: In vitro culture and $\left[{ }^{1} \mathrm{H}\right]$ NMR characterization of amastigote-like forms. Mol. Cell Biochem. 1995, 142, 89-97. [CrossRef] [PubMed]

59. Abeje, F.; Bisrat, D.; Hailu, A.; Asres, K. Phytochemistry and antileishmanial activity of the leaf latex of Aloe calidophila Reynolds. Phytother. Res. 2014, 28, 1801-1805. [CrossRef] [PubMed]

60. Rampersad, S.N. Multiple applications of Alamar Blue as an indicator of metabolic function and cellular health in cell viability bioassays. Sensors 2012, 12, 12347-12360. [CrossRef] [PubMed]

61. Cote, C.K.; van Rooijen, N.; Welkos, S.L. Roles of macrophages and neutrophils in the early host response to Bacillus anthracis spores in a mouse model of infection. Infect Immun. 2006, 74, 469-480. [CrossRef]

62. Welkos, S.L.; Trotter, R.W.; Becker, D.M.; Nelson, G.O. Resistance to the Sterne strain of B. anthracis: Phagocytic cell responses of resistant and susceptible mice. Microb. Pathog. 1989, 7, 15-35. [CrossRef]

63. Dutra, F.L.; Oliveira, M.M.; Santos, R.S.; Silva, W.S.; Alviano, D.S.; Vieira, D.P.; Lopes, A.H. Effects of linalool and eugenol on the survival of Leishmania (L.) infantum chagasi within macrophages. Acta Trop. 2016, 164, 69-76. [CrossRef]

64. Montrieux, E.; Perera, W.H.; García, M.; Maes, L.; Cos, P.; Monzote, L. In vitro and in vivo activity of major constituents from Pluchea carolinensis against Leishmania Amazon. Parasitol. Res. 2014, 113, 2925-2932. [CrossRef] [PubMed]

65. Borborema, S.E.T.; Schwendener, R.A.; Osso Jr, J.A.; de Andrade Jr, H.F.; do Nascimento, N. Uptake and antileishmanial activity of meglumine antimoniate-containing liposomes in Leishmania (Leishmania) major-infected macrophages. Int. J. Antimicrob. Agents 2011, 38, 341-347. [CrossRef]

66. Chanmol, W.; Jariyapan, N.; Somboon, P.; Bates, M.D.; Bates, P.A. Axenic amastigote cultivation and in vitro development of Leishmania orientalis. Parasitol. Res. 2019, 118, 185-189. [CrossRef]

67. Paladi, C.S.; Pimentel, I.A.S.; Katz, S.; Cunha, R.L.O.R.; Judice, W.A.S.; Caires, A.C.F.; Barbiéri, C.L. In vitro and in vivo activity of a palladacycle complex on Leishmania (Leishmania) amazonensis. PLoS Negl. Trop. Dis. 2012, 6, e1626. [CrossRef]

68. Poorrajab, F.; Ardestani, S.K.; Foroumadi, A.; Emami, S.; Kariminia, A.; Behrouzi-Fardmoghadam, M.; Shafiee, A. Selective leishmanicidal effect of 1,3,4-thiadiazole derivatives and possible mechanism of action against Leishmania species. Exp. Parasitol. 2009, 121, 323-330. [CrossRef] [PubMed]

69. Dutta, A.; Bandyopadhyay, S.; Mandal, C.; Chatterjee, M. Development of a modified MTT assay for screening antimonial resistant field isolates of Indian visceral leishmaniasis. Int. J. Parasotol. 2005, 54, 119-122. [CrossRef]

70. Löfgren, S.E.; Miletti, L.C.; Steindel, M.; Bachere, E.; Barracco, M.A. Trypanocidal and leishmanicidal activities of different antimicrobial peptides (AMPs) isolated from aquatic animals. Exp. Parasitol. 2008, 118, 197-202. [CrossRef]

71. Malagoli, D. A full-length protocol to test hemolytic activity of palytoxin on human erythrocytes. Invertebr. Surviv. J. 2007, 4, 92-94.

72. Dayeh, V.R.; Chow, S.L.; Schirmer, K.; Lynn, D.H.; Bols, N.C. Evaluating the toxicity of Triton X-100 to protozoan, fish, and mammalian cells using fluorescent dyes as indicators of cell viability. Ecotoxicol. Environ. Saf. 2004, 57, 375-382. [CrossRef] 
73. Somboonwiwat, K.; Marcos, M.; Tassanakajon, A.; Klinbunga, S.; Aumelas, A.; Romestand, B.; Gueguen, Y.; Boze, H.; Moulin, G.; Bachère, E. Recombinant expression and anti-microbial activity of anti-lipopolysaccharide factor (ALF) from the black tiger shrimp Penaeus monodon. Dev. Comp. Immunol. 2005, 29, 841-851. [CrossRef]

74. Valadares, D.G.; Duarte, M.C.; Oliveira, J.S.; Chávez-Fumagalli, M.A.; Martins, V.T.; Costa, L.E.; Leite, J.P.V.; Santoro, M.M.; Régis, W.C.; Tavares, C.A.; et al. Leishmanicidal activity of the Agaricus blazei Murill in different Leishmania species. Parasitol. Int. 2011, 60, 357-363. [CrossRef] [PubMed]

75. Dathe, M.; Schümann, M.; Wieprecht, T.; Winkler, A.; Beyermann, M.; Krause, E.; Matsuzaki, K.; Murase, O.; Bienert, M. Peptide helicity and membrane surface charge modulate the balance of electrostatic and hydrophobic interactions with lipid bilayers and biological membranes. Biochemistry 1996, 35, 12612-12622. [CrossRef] [PubMed]

76. Lombardo, F.C.; Pasche, V.; Panic, G.; Endriss, Y.; Keiser, J. Life cycle maintenance and drug-sensitivity assays for early drug discovery in Schistosoma mansoni. Nat. Protoc. 2019, 14, 461-481. [CrossRef] [PubMed]

77. Hu, S. Medicine Containing Anemonin as Effective Component for Treating Aseptic Inflammation. EP 1252893 B1, 10 December 2008. 